\title{
Substitution Under \\ Federal Rule of Civil Procedure 25(d): Mootness and Related Problems
}

Although private suits against the government may be barred by the doctrine of sovereign immunity, ${ }^{1}$ it has long been recognized that in certain circumstances a private litigant may seek equitable relief "intrinsically against the government" by naming a government officer as defendant. ${ }^{2}$ These cases present particular difficulties when the named defendant, for whatever reason, leaves office during the course of the litigation and is succeeded. At common law, a successor could not be substituted as defendant in a suit that had been brought against the predecessor in his official capacity unless a statute or court rule permitted the substitution; ${ }^{3}$ the action was said to abate. ${ }^{4}$ A plaintiff thwarted by a succession in office would thus have to begin the litigation anew in order to acquire the desired relief. ${ }^{5}$ Since the subsequent suit generally involved the relitigation of numerous issues, ${ }^{6}$ the abatement doctrine has been widely and properly criticized for causing the waste of both judicial and personal resources. ${ }^{7}$

1 See generally 3 K. Davis, Administrative LaW Treatise $\S \S 27.01-27.05,27.09$ (1958).

2 E.g., Philadelphia Co. v. Steinson, 223 U.S. 605 (1912); Ex parte Young, 209 U.S. 123 (1908). See generally Davis, Sovereign Immunity in Suits Against Officers for Relief Other than Damages, 40 CoRnell L.Q. 3 (1954); Block, Suits Against Officers and the Sovereign Immunity Doctrine, 59 HARv. L. REv. 1060 (1946).

3 See, e.g., United States ex rel. Bernadin v. Butterworth, 169 U.S. 600 (1898); United States v. Boutwell, 84 U.S. (17 Wall.) 604 (1873).

The term "successor" includes any government official who succeeds to the powers of the defendant named in the original action. Thus, if the defendant's office is abolished but its powers are transferred to another department, the officer who succeeds to those powers is a "successor." The courts have typically treated such transfers as successions for the purpose of applying a substitution statute. E.g., Wright v. County School Board, 309 F. Supp. 671 (E.D. Va. 1970), rev'd on other grounds sub nom., Wright v. Council of City of Emporia, 442 F.2d 570 (4th Cir. 1971), rev'd, 407 U.S. 451 (1972); Jackson v. Dept. of Public Welfare, 317 F. Supp. 1151 (M.D. Fla. 1970); accord, Fleming v. Mohawk Wrecking \& Lumber Co., 331 U.S. 111 (1947).

- Abatement means dismissal of the action without prejudice to the right of the plaintiff to bring a similar action against the successor in office at a later time. $C f$. Acheson v. Furusho, 212 F.2d 284, 286, 288 (9th Cir. 1954).

${ }^{3}$ A succession did not, of course, abate a suit seeking money damages from the predecessor personally. As a logical matter, the predecessor's separation from office has no effect on the litigation.

- The only new issue likely to arise would be whether the successor had repeated the conduct originally challenged.

' See, e.g., Irwin v. Wright, 258 U.S. 219, 224 (1922); United States ex rel. Bernadin v. 
The abatement doctrine in cases involving the succession of public officers has been eliminated under the Federal Rules of Civil Procedure. Rule 25(d)(1) provides that a successor is to be automatically substituted in a suit pending against his predecessor. ${ }^{8}$ Automatic substitution does not, however, resolve all of the problems created by a succession in office. Rule 25(d) substitution is purely procedural; $;$ the litigation can continue only if, as a matter of substantive law, the controversy survives the substitution. ${ }^{10}$ In other words, even though a succession in office will no longer abate a controversy, it may effectively moot the suit and compel a dismissal.

The problem of mootness in rule $25(\mathrm{~d})$ cases is particularly acute when the plaintiff seeks to enjoin a government officer from continuing to engage in a certain course of conduct. ${ }^{11}$ When substitution occurs in such a case for injunctive relief in futuro, critical importance attaches to the allocation of the burden of proof on the

Butterworth, 169 U.S. 600, 605 (1898). See generally 3B J. Moore, Federal Practice ๆ 25 (2d ed. 1974); Comment, Abatement-Status of Suit Nominally Against Government Official When Official Leaves Office, 50 Mich. L. Rev. 443, 445 (1952); Davis, Suing the Government by Falsely Pretending to Sue an Officer, 29 U. CHI. L. Rev. 435, 451 (1962); Note, Developments in the Law: Remedies Against the United States and Its Officials, 70 Harv. L. REv. 829, 831-34 (1957); Comment, Abatement for Failure to Make Proper Substitution, 5 MiAMI L.Q. 611, 612 (1951).

${ }^{8}$ Fed. R. Civ. P. 25(d) provides:

(1) When a public officer is a party to an action in his official capacity and during its pendency dies, resigns, or otherwise ceases to hold office, the action does not abate and his successor is automatically substituted as a party. Proceedings following the substitution shall be in the name of the substituted party, but any misnomer not affecting the substantial rights of the parties shall be disregarded. An order of substitution may be entered at any time, but the omission to enter such an order shall not affect the substitution.

(2) When a public officer sues or is sued in his official capacity, he may be described as a party by his official title rather than by name; but the court may require his name to be added.

Rule 25(d)(1) was amended in 1961 to eliminate the necessity of demonstrating, as a condition of the substitution, that the successor intended to continue the predecessor's policies. See text and notes at notes 20-22 infra. The rules for the Supreme Court and the United States Courts of Appeals contain equivalent provisions. Sup. Ct. Rule 48(3); Fed. R. APP. P. 43(c).

- See Advisory Committee's Note to Rule 25(d) (1961) [hereinafter referred to as Note].

11 As a purely procedural measure, rule 25 (d) can have no impact on whether either sovereign immunity or the eleventh amendment will be available bars. Rule 25(d) could not, nor was it intended to, create liabilities that did not previously exist. 3B J. MoORE, FEDERaL Practice Tा 25-404.

"Cases seeking such relief, often termed "injunctions in futuro," will be the focus of this comment. Although rule 25(d) is intended to operate in a broader range of cases, see note 20 infra, the relief sought in those cases might pose special practical difficulties that call for modifying the allocation of the burden of establishing mootness that is recommended herein. 
question of mootness. In Spomer $v$. Littleton, ${ }^{12}$ the only Supreme Court decision in which the effect of a rule 25(d) substitution has played a central role, the Court remanded the case without adjudicating its merits in order to give the plaintiff-respondent an opportunity to demonstrate that the controversy had not been mooted by succession. ${ }^{13}$ If, as in Spomer, all plaintiffs seeking injunctive relief in futuro are required to establish that the controversy has not been mooted by a substitution of named defendants, then the procedure of rule $25(\mathrm{~d})$ may be turned into an empty formality as inefficient as the abatement doctrine. Requiring the defendant to prove mootness, on the other hand, would rarely generate inefficiency or injustice. Either the successor intends to continue the allegedly improper conduct, in which case it is difficult to conclude that he is prejudiced by litigating the case sooner rather than later, or he intends to discontinue the behavior, in which case he should be allowed to moot the case by so declaring. ${ }^{14}$ At first glance, then, common sense suggests the desirability of allocating the burden on the issue of mootness to the successor in cases where the plaintiff has sought injunctive relief against the predecessor in his official capacity.

After reviewing the history of federal substitution measures, this comment examines amended federal rule 25(d)(1) and argues that the rule was intended to place the burden of establishing mootness on the successor. Spomer and its progeny are then discussed and it is argued that the result in Spomer-requiring the plaintiff to establish non-mootness-is best understood as a narrow though ill-defined exception to the general rule allocating the burden to the successor. Finally, the comment argues that the principles underlying certain closely related and well established doctrines provide further support for placing the burden of establishing mootness on the successor, and suggests that this burden should be satisfied by a good faith disavowal of the contested policy.

12414 U.S. 514 (1974); see text and notes at notes 35-50 infra. See also Two Guys from Harrison-Allentown, Inc. v. McGinley, 366 U.S. 582 (1961) in which rule 25(d) played a minor role.

13 On remand, the Court of Appeals for the Seventh Circuit held that the case was moot. Littleton v. Berbling, No. 71-1395 (Jan. 15, 1975) (unpublished opinion not to be cited per 7TH CIR. R. 28).

14 See text and notes at notes 99-100 infra. A difficult intermediate case arises when the successor claims to have a good faith doubt concerning his intent to continue the challenged behavior. It will be argued that the successor should be required either to disavow the policy or defend its legality in the current suit since the likelihood of continued prejudice to the plaintiff is solely within the successor's control. Id. 


\section{Federal Measures Governing Substitution of SUCCESSOR OFFICERS}

A. Substitution Prior to 1961

United States v. Boutwell ${ }^{15}$ firmly established in the United States the common law rule that an action against a public officer in his official capacity abates, in the absence of contrary statutory authority, upon his separation from office during the pendency of an action. Boutwell was an action seeking a writ of mandamus to compel the Secretary of the Treasury to pay the amount due on certain Treasury orders. During appeal of the denial of the writ, the claimants unsuccessfully sought to substitute the successor to the original named defendant. In affirming the result below, the Supreme Court conceded that the claimants might have been seeking the satisfaction of an official and enduring governmental obligation rather than a duty personal to the predecessor. Nevertheless, the Court held that the action abated because the relief sought was necessarily personal to the predecessor. The Court noted that the successor was neither in privity with nor the agent of his predecessor and, in essence, instructed the claimants to seek payment from the successor before seeking judicial intervention.10

Because the abatement doctrine often forced private plaintiffs to follow round-about procedures and tended to waste judicial resources, ${ }^{17}$ the doctrine has been modified by various federal statutes and court rules since 1899. None of the pre-1961 rules, however, provided for automatic substitution, but instead conditioned substitution on a demonstration by the plaintiff that there was a need to continue the action against the successor. ${ }^{18}$ Independent issues of

1584 U.S. (17 Wall.) 604 (1873). See also United States ex rel. Bernadin v. Butterworth, 169 U.S. 600 (1898); Warner Valley Stock Co. v. Smith, 165 U.S. 28 (1896); United States ex rel. Warden v. Chandler, 122 U.S. 643 (1887).

16 84 U.S. at 607.

17 The Supreme Court recognized the need for statutory modification of the abatement doctrine in United States ex rel. Bernadin v. Butterworth, 169 U.S. 600, 605 (1898), and then again in Irwin v. Wright, 258 U.S. 219, 224 (1922).

18 The 1899 Act, 30 Stat. 822 (1899), provided for substitution of federal officials "on motion or supplemental pleading filed, ... showing a necessity for the survival" of the action. See Caledonia Coal Co., v. Baker, 196 U.S. 432 (1905).

The 1925 Act, 43 Stat. 936, 941 (1925), provided for substitution of federal, state, and local government officers upon a showing "that there is a substantial need for . . . continuing and maintaining the cause and obtaining an adjudication of the question involved." $E . g ., E x$ parte La Prade, 289 U.S. 444 (1933); Allen v. Regents of the University System of Georgia, 304 U.S. 439 (1938).

The 1925 Act later became the original rule 25(d) of the Federal Rules of Civil Procedure. See 3B J. Moore, Federal Practice ๆ 25.01. The Rule was amended in 1948 to alter the time 
mootness never arose, therefore, as a result of substitution under these rules; if succession made the controversy moot, the plaintiff would be unable to demonstrate a continuing need for the litigation and substitution would be denied. Thus, even though substitution was possible under the pre-1961 rules, if the plaintiff could not demonstrate that the successor was continuing or threatening to continue his predecessor's alleged misconduct, the litigation would be dismissed. ${ }^{19}$ As under Boutwell, the plaintiff thwarted by a succession would be unlikely to have his claim adjudicated until the successor committed an overt act that re-invigorated the controversy.

\section{B. The 1961 Amendments to Rule 25(d) and Mootness}

In 1961 rule 25(d) was amended to eliminate the abatement doctrine as applied to government officers sued in their official capacity in federal courts. ${ }^{20}$ Specifically, the new rule provides for automatic substitution of successors as defendants and deletes the requirement of making a substantial showing of "need for . . . continuing and maintaining" the action. ${ }^{21}$ To simplify the procedure of substitution further, rule $25(\mathrm{~d})(2)$ permits an action to describe the officer by title instead of by name, unless the court requires that the name be inserted. Although the amended rule assures that actions against public officers will not abate by providing for automatic substitution, the presence of the successor in court as a party defendant cannot require the court to continue to hear the case if a case or controversy no longer exists. ${ }^{22}$ The rule thus clearly shifts the

limit for moving for substitution, but the other provisions were left substantially unchanged. See Johnson v. Yielding, 165 F. Supp. 76 (N.D. Ala. 1958).

Rule 25(d) was again amended in 1961. See text and notes at notes 21-34 infra.

${ }^{19}$ See, e.g., McGrath v. National Association of Manufacturers, 344 U.S. 804 (1952), reviewed in Davis, Government Officers as Defendants: Two Troublesome Problems, $104 \mathrm{U}$. PA. L. REv. 69, 85 (1955); Gorham Mfg. Co. v. Wendell, 261 U.S. 1 (1923); Shaffer v. Howard, 249 U.S. 200 (1919).

${ }^{20}$ The Advisory Committee on Rules's notes indicate that the Rule is intended to operate in suits "in form against a named officer, but intrinsically against the government or the office or the incumbent." The notes listed certain examples: to compel performance of official duties, to obtain judicial review of official orders, to prevent officers from acting in excess of their authority or unconstitutionally. Note, note 9 supra.

${ }^{21}$ Fed. R. Civ. P. 25(d) (1960). The Advisory Committee on Rules noted that "[u]nder the Amendment, the successor is automatically substituted as a party without an application or showing of need to continue the action." Note, note 9 supra.

22 This point is made in Spomer, 414 U.S. at 521 n.9. The Supreme Court has based its recent mootness decisions on the "case or controversy" requirement of article III of the Constitution. An article III court lacks jurisdiction over a moot action because of the absence of a "case or controversy." See Note, The Mootness Doctrine in the Supreme Court, 88 Harv. L. REv. 373, 375 (1974) (citing cases). 
court's attention from the propriety of substitution to the propriety of continuing the litigation after substitution.

Since amended rule 25(d) magnifies the significance of the mootness question and does not expressly allocate the burden of proof, determining the proper allocation will be a central concern to the litigants and the courts. Allocating the burden to the plaintiff may result in duplicative litigation and may unnecessarily expose the plaintiff to further harm. Allocating the burden to the successor, on the other hand, may force him to defend the legality of conduct that he does not intend to pursue and may force the court to render an essentially advisory opinion. It is important, therefore, to determine if amended rule 25(d) was intended to allocate the burden of establishing mootness, and if so, how.

Two points are clear: rule 25(d) cannot allocate the burden of establishing mootness to one party in a given case or in general if the relevant substantive law has allocated it to the other. Such a change in the substantive law would be forbidden by the Rules Enabling Act. ${ }^{23}$ Moreover, even if rule 25(d) were to allocate this burden clearly, a court has the authority to dismiss a case sua sponte on the ground of mootness; a case or controversy being crucial to a court's jurisdiction, the court can notice on its own motion that its jurisdiction has ceased to exist because substitution has mooted the case or controversy. ${ }^{24}$

Although rule 25(d)'s allocation of the burden of establishing mootness will not always be important-such as where there is a clear absence of jurisdiction-it will be significant where in futuro injunctive relief is sought against a successor government officer. First, since mootness did not arise as an independent issue prior to the 1961 amendments, rule 25(d) could allocate the mootness burden to either party without conflicting with established substantive law. Second, since it generally will be difficult to predict whether the successor intends to continue the contested policies of his predecessor, the mootness issue will rarely be sufficiently clear to warrant

In Flast v. Cohen, 392 U.S. 83 (1968) the Court noted that one purpose of the case or controversy requirement is to "limit the business of federal courts to questions presented in an adversary context and in a form historically viewed as capable of resolution through the judicial process." Id. at 95. Although the issue that most commonly arises is whether the plaintiff has a sufficient interest in the case to ensure the necessary adverseness, in substitution cases the question is whether the defendant has a sufficient interest in the case to ensure adverseness.

${ }^{23} 28$ U.S.C. § 2072 (1970); cf. Hanna v. Plummer, 380 U.S. 460 (1965).

24 See Golden v. Zwickler, 394 U.S. 103 (1969); Zwickler v. Koota, 389 U.S. 241 (1967). See generally 6A J. Moore, Federal Practice If 57.13, at 57-121 to 57-125 (2d ed. 1974); Diamond, Federal Jurisdiction to Decide Moot Cases, 94 U. PA. L. Rev. 125, 126 (1946). 
spontaneous judicial resolution; in any given case an examination of the originally challenged behavior may well prove inconclusive. ${ }^{25}$ Given this setting, several factors suggest that amended rule 25(d) was intended to require the substituted successor to establish mootness as a general rule.

First, the Advisory Committee on Rules concluded that amended rule 25(d) would place the burden of establishing mootness on the successor-defendant. Although the Committee's opinion cannot be granted conclusive weight-as a practical matter, the Committee's intent lacks the force of a legislature's-it certainly merits considerable deference. ${ }^{26}$ After observing that the requirement of a "showing that there is a substantial need for continuing the litigation . . . can rarely serve any useful purpose and fastens a burdensome formality, "2t the Committee notes state:

When the successor does not intend to pursue the policy of his predecessor which gave rise to the lawsuit, it will be open to him, after substitution, ... . to seek to have the action dismissed as moot or to take other appropriate steps to avert a judgment or decree. ${ }^{28}$

This language led one commentator writing soon after the amendment was approved to conclude that rule 25(d) would henceforth require the successor to establish mootness. ${ }^{29}$ It also led Justice

${ }^{25}$ But see Spomer v. Littleton, 414 U.S. 514 (1974).

${ }^{26}$ In Spomer, the Court relied on the Advisory Committee notes in construing the rule.

${ }^{27}$ Note, note 9 supra.

${ }^{23}$ Id. The Committee Note then cites the following cases as being contrary to the principle of the amended rule, Ex parte La Prade, 289 U.S. 444 (1933); Allen v. Regents of the University System of Georgia, 304 U.S. 439 (1938); McGrath v. National Association of Manufacturers, 344 U.S. 804 (1952); Danenberg v. Cohen, 213 F.2d 944 (7th Cir. 1954). These succession cases, decided under the pre-1961 substitution measures, required the plaintiff to demonstrate that the controversy survived the succession as a condition for substitution.

29 Kaplan, Amendments of the Federal Rules of Civil Procedure, 1961-1963 (I), 77 Harv. L. Rev. 601, 606-09 (1964). See also 3B J. Moore, Federal Practice ๆ 25.09.

Professor Wright has argued, $2 \mathrm{~W}$. Barron \& A. Holtzoff, Federal Practice and Procedure, \$ 626, at 448-49 (C. Wright ed. 1961), cited with approval, Hirsh v. Green, 382 F. Supp. 187, 190 (D. Md. 1974), that the amended rule can only shift the burden of establishing mootness to successors in cases involving federal officers; the burden must remain unchanged in cases involving succession of state public officials. This argument is based on a statement in Ex parte La Prade, 289 U.S. 444 (1933), a case disapproved by the Advisory Committee on Rules, see note 28 supra, to the effect that even though a federal statute (such as a substitution statute) could make a federal officer privy to the liabilities of his predecessor-officers, it could not do so for state officers. Id. at 458. Wright's reliance on $L a$ Prade is misplaced, however. Rule 25(d) does not make a successor a privy to the liabilities of his predecessor; rather it enables a suit against a government officer to continue uninterrupted by a succession in office. In light of the purely procedural nature of the Federal Rules of Civil Procedure, it could scarcely be argued that a successor could be held liable for the 
Douglas to this conclusion. Justice Douglas's dissent from the Supreme Court's approval of rule 25(d) was based largely on his preference for the pre-amendment practice which, he claimed, implicitly required the plaintiff to establish that the case had not been mooted by succession. ${ }^{30}$ The majority of the Court did not quarrel with Justice Douglas's conclusions as to how the rule would operate, but simply noted their approval of the change. ${ }^{31}$

The operation of the amended rule is also suggestive of an intent to burden the successor-defendant with establishing mootness. If, under rule $25(\mathrm{~d})(1)^{32}$ the officer sued in his official capacity is listed by name as the party defendant, the successor is to be automatically substituted as defendant upon taking office. Thus the court need not become aware of the substitution. Moreover, rule $25(d)(2)^{33}$ permits a public officer sued in his official capacity to be described by his official title rather than by name unless the court directs that his name be included ${ }^{34} \mathrm{~A}$ succession in office is not apt to come to the attention of the court under this provision as well.

Rule 25(d), it has been seen, expressly eliminates the abatement doctrine as well as the requirement that the plaintiff demonstrate a need for continuing the litigation. The rule replaces these doctrines with an automatic rule of substitution designed to operate without the knowledge of the court. Placing the burden of establishing mootness on the defendant would be entirely compatible with the operation of the amended rule. Since the rule embodies an implicit judgment that succession and substitution have no bearing on the existence of a continuing controversy, the successor who brings the substitution to the court's attention should logically have the burden of establishing its significance; in other words, the successor should be required to demonstrate to the court that the substitution that otherwise would have occurred without its knowledge has had the effect of mooting the case or controversy.

personal liabilities of his predecessor. See text and notes at 23-25 supra. If rule 25(d) sought to accomplish such a result, it would presumably be invalid in its application to all officers, both state and federal. See 5 J. Moore, Federal Practice $\{43.08$, at 1360-61 (2d ed. 1974).

so 368 U.S. 1009, 1012 (1968).

I1 368 U.S. 1009 (1961).

32 See note 8 supra.

${ }^{33}$ Id.

s See Elliott v. Federal Home Loan Bank Board, 233 F. Supp. 578, 590 (S.D. Cal. 1964), rev'd on other grounds, 386 F.2d 42 (9th Cir. 1968). 


\section{Mootness in Succession Cases After 1961}

\section{A. Spomer v. Littleton}

Spomer $v$. Littleton ${ }^{35}$ was the first Supreme Court case since the enactment of the 1961 amendments which was decided on the basis of the mootness issue arising from a rule $25(\mathrm{~d})$ substitution of party defendant. ${ }^{36}$ Spomer was a civil rights class action brought against Peyton Berbling, the then State's Attorney, alleging that he practiced racial discrimination in the exercise of his prosecutorial functions. The plaintiff class sought, inter alia, an in futuro injunction prohibiting the continuation of that behavior. After the Seventh Circuit held on appeal from the dismissal below that a prosecutor does not enjoy absolute immunity from injunctive proscription, ${ }^{37} \mathrm{~W}$. C. Spomer was elected State's Attorney and succeeded Berbling. Invoking the automatic substitution procedure of Supreme Court rule $48(3)$, Spomer successfully petitioned for certiorari to review the decision of the Court of Appeals. ${ }^{38}$

Although the Supreme Court was aware of the substitution when it granted certiorari on the question of the scope of prosecutorial immunity, it nonetheless resolved the case on mootness grounds. Without having benefited from briefs of counsel on the subject, the Court doubted that the case presented a concrete controversy between Spomer and respondents. The Court vacated the Seventh Circuit's opinion and remanded the case to that court for a determination of whether the case was in fact moot and whether respondents should be permitted to amend their complaint..39 In effect, the Court remanded to enable plaintiffs-respondents to attempt to show a need for continuing the litigation.

The intended scope of Justice White's opinion for the unanimous Court is exceedingly difficult to gauge. There is language in the opinion which, if read literally, would completely undermine the intent of the 1961 amendment. For example, the Court noted that Spomer was neither named as a defendant nor was his conduct cited in the complaint; yet the point of the recitation is unclear since this situation will be the norm in a rule $25(\mathrm{~d})$ substitution case. The

${ }^{35} 414$ U.S. 514 (1974).

36 Actually, the substitution in Spomer was pursuant to Supreme Court Rule 48(3), but, as the Court noted, the wording of rule 48(3) was based on and is substantially identical to rule 25(d). In fact, the Spomer Court relied on language from the Advisory Committee notes to rule 25 (d) in interpreting its rule. 414 U.S. at 521 n.9.

37 Littleton v. Berbling, 468 F.2d 389 (7th Cir. 1972).

${ }^{38} 411$ U.S. 915 (1973).

37414 U.S. at 520-21. 
Court also observed that the claimants did not allege that "Spomer intends to continue the asserted practices of Berbling of which they complain."40 Rule 25(d), however, eliminated both the abatement doctrine and the requirement of demonstrating a need to continue the litigation; the Court's language arguably reinvigorates these doctrines. Finally, in a footnote, the Court noted that the "automatic substitution" provision was intended to operate whenever "effective relief would call for corrective behavior" by the successor rather than the predecessor and that in applying this standard it is necessary to determine if the controversy has survived the succession. ${ }^{41}$ If, by this statement, the Court meant that a finding of mootness makes a case non-justiciable, it was saying nothing exceptional. But, on the other hand, if the Court was indicating that rule 25(d) substitution is to be conditioned upon the plaintiff showing that the controversy will survive the substitution, it was for all practical purposes rewriting the rule.

It is doubtful, however, that the Court disagreed with the Advisory Committee's assessment of the intent of rule 25(d) or believed that rule 25(d) could not allocate the mootness burden to the successor; if it had, it presumably would have so stated. The Court must have had something else in mind. The key to this otherwise mysterious opinion is perhaps contained in one sentence where the Court hinted that the case did not truly involve "a claim against a government officer in his official capacity" within the meaning of the substitution rule. The Court observed that "[ $t]$ he wrongful conduct charged in the complaint is personal to Berbling, despite the fact that he was also sued in his then capacity as State's Attorney." "12 In other words, even though the Supreme Court had earlier allowed substitution under a rule involving substitution of successors to officers sued in their official capacity, it had come to realize that the alleged misconduct was probably personal and therefore outside the area in which the rule's policies were intended to operate.

This reading of the case is supported by the otherwise paradoxical citation of Allen $v$. Regents of University System of Georgia ${ }^{43}$ for the proposition that Spomer appeared moot because the complainants had not alleged facts indicating the continuation of the controversy after the succession. ${ }^{44}$ Allen had been cited by the Rules Advi-

\footnotetext{
10 Id. at 521 .

4 Id. at 521 n.41.

12 Id. at 521 .

ts 304 U.S. 439 (1938).

" 414 U.S. at 521.
} 
sory Committee as a case contrary to the spirit of amended rule $25(\mathrm{~d})^{45}$ since it required the plaintiff to establish a need for continuing the litigation. Its citation in Spomer, as well as the Court's other observations, would be explicable only if, on its facts, Spomer was outside the area in which rule 25(d) was intended to allocate the burden of establishing mootness to the successor. In other words, Spomer is reasonable if the underlying claim in the case is viewed as being only nominally against a government officer in his official capacity while in reality being against the officer in his personal capacity. Under this reading, Spomer would create a novel category of behavior-personal official action. Certain official-appearing actions would be considered to be too "personal" for rule 25(d) purposes in the absence of allegations that the actions complained of were in fact official policies not personal to the predecessor.

If correct, this reading of Spomer is troublesome because there is a wide range of governmental activity that could conceivably be characterized as "personal official action." In one sense it could be argued that all official action by a public officer is "personal" since it is his individual responses to the duties he undertook when he assumed office. ${ }^{46}$ Under this view, however, the exception would swallow the rule. On the other hand, Spomer might be read as contemplating a distinction between ministerial and discretionary action, since only the latter involves the exercise of subjective and therefore personal judgment. Yet this standard may also be unworkable, posing hopeless problems of linedrawing and conceptualization. ${ }^{47}$ Moreover, a discretionary decision can, if exercised consistently, become an official policy. Finally, Spomer might be read as contemplating a general distinction between those actions of an officer that bespeak an official policy and those that do not. Although this standard would nesessarily be ambiguous as well, "nonpersonal" or "official" conduct within the scope of rule 25(d) could be defined as conduct involving a reasonable probability of repetition. ${ }^{48}$ There is no point in continuing the litigation if the predecessor's behavior appears to be unique or so idiosyncratic that it is unlikely to be repeated by the successor. Otherwise, official action

${ }^{15}$ See note 28 supra.

18 The Supreme Court basically adopted this position in United States v. Boutwell, 84 U.S. (17 Wall.) 604 (1873).

47 Professor Davis, for example, concluded that the ministerial/discretionary distinction has "no affirmative justification" and has proven "unworkable in the context of actions for writs of mandamus." K. Davis, Administrative Law, Cases, Text, Problems 167 (1973).

${ }^{18}$ See text and notes at note 88-100 infra. 
should be considered to be official and the substitution should not affect the litigation.

Since the Spomer decision does not disclose the breadth of the exception it announces, it is necessary to look at other authorities to determine when a plaintiff seeking in futuro injunctive relief against a successor government official must demonstrate that the controversy has survived the succession..$^{49} \mathrm{~A}$ finding of mootness, it must be remembered, does not conclusively deny the plaintiff's requested relief; but it does require the entire proceedings to be vacated, thus forcing the plaintiff to wait for either a threat or an additional harmful act before beginning the litigation anew. Both practicality and policy suggest that Spomer should be read as creating only a narrow exception to the general rule placing the burden of establishing mootness on the successor-defendant. There is some indication that the lower courts have already begun to give Spomer such a narrow reading. ${ }^{50}$

\section{B. Lower Court Succession Cases After Spomer}

The lower courts have been confronted with the mootness issue arising from a rule 25(d) substitution on several occasions since Spomer was decided. Although these cases do not, when taken as a whole, precisely delineate the circumstances in which the plaintiff will be obligated to establish non-mootness, they do suggest a tendency to read Spomer narrowly, placing the burden on the plaintiff only where the original defendant's conduct was clearly based on a personal rather than an official policy.

In a small number of cases, as in Spomer, courts acting on their own motion have been able to conclude with ease that a case has been mooted by an official succession. In Safeguard Mutual Life Ins. Co. $v$. Pennsylvania, ${ }^{51}$ a suit for injunctive and declaratory relief, it was alleged that the Insurance Commissioner, George F. Reed, "through his authorized agents, ... . unlawfully and maliciously used various provisions of the Insurance Acts in an effort to circumvent an order of the Dauphin County Court . . ." in order to injure the plaintiff. ${ }^{52}$ Following the appointment and substitution of a new Commissioner during the pendency of the litigation, the court, after

1 The irreparable harm necessary to support an injunctive order should not be confused with whether the controversy has become moot. It is quite possible that the litigation after the substitution will demonstrate that the injunction should not issue.

so See text and notes at notes 51-74 infra.

s1 372 F. Supp. 939, 946, 948-49 (E.D. Pa. 1974).

52 Id. at 944. 
discussing Spomer extensively, held the action for injunctive relief moot; the court noted that the wrongful conduct challenged was personal to the predecessor and that no allegations had been made that the successor was engaged in similar misconduct.. ${ }^{53} \mathrm{~A}$ similar case, Lusk v. McDonough, ${ }^{54}$ was an action seeking declaratory relief from the informal rule of defendant state judge forbidding courtroom appearances by women wearing slacks. The action was held to have been mooted by the defendant's separation from office. Again, as in Safeguard, the court emphasized the personal character of the alleged misconduct and the failure to assert a threat of repetition by the successor. ${ }^{55}$

Both Safeguard and $M c D o n o u g h$ were straightforward cases falling squarely within the narrow confines of Spomer; in each case the court could easily conclude that the alleged misconduct-a malicious abuse of authority in the one case and an idiosyncratic informal rule in the other-was so personal that there was virtually no likelihood of repetition by the successors. Since the likelihood of a continued controversy was virtually nonexistent, the courts recognized their clear lack of jurisdiction and held the cases moot on their own motion..$^{56}$

In most of the cases since Spomer, however, a full hearing on the merits has followed the automatic substitution, although the opinions rarely include a careful discussion of the mootness question. Typical of these cases is Cabrera $v$. Municipality of Bayamon, ${ }^{57}$ in which the court summarily concluded that Spomer was "different, not merely distinguishable." ${ }^{58}$ Cabrera was a class action by town residents seeking to enjoin the municipality, the Mayor and the Head of the Municipal Dumps Operation System from continuing to operate a dump near their land. The district court issued the

${ }^{53}$ Id. at 948-49. Plaintiff also sought reinstatement of his insurance license. The court held, without relying on Spomer, that this aspect of the case was also moot because plaintiff had already been reinstated by the state court. Id. at 949 . Had plaintiff not been reinstated, the court may have been willing to recognize the existence of a continuing controversy despite the succession. See text and notes at notes 57-64 infra.

st 386 F. Supp. 183 (E.D. Tenn. 1974).

${ }_{55}$ Id. at 186 n.2. See also Hirsh v. Green, 382 F. Supp. 187 (D. Md. 1974). In Hirsh, the court arguably misapplied Spomer in holding that an action by a discharged employee against two state officials for declaratory relief from his allegedly unlawful and unconstitutional dismissal became moot when the two named officials were succeeded. This case is not germane to the analysis, however, because the successors were the ones who moved to have the suit declared moot.

s6 See text and note at note 25 supra.

370 F. Supp. 859 (D.P.R. 1974).

ss Id. at 871 . 
injunction even though both named defendants had been succeeded prior to its issuance. ${ }^{59}$ The court decided that Spomer did not foreclose it from requiring the successors to take affirmative steps to abate the pollution, ${ }^{80}$ intimating that the finding of mootness in Spomer was based on the Supreme Court's reluctance to reach the merits. ${ }^{61}$

Although the court did not suggest any explanation for its result, Cabrera is characteristic of quite a few cases decided under amended rule $25(\mathrm{~d})$ in which mandatory injunctive relief from a current and continuing injury is sought. ${ }^{82}$ The issue in these cases is whether the successor will be allowed to permit the effects of the predecessor's alleged misconduct to harm the plaintiff. ${ }^{63}$ Such cases can hardly come within Spomer, despite the theoretical uncertainty concerning the successor's future action, because the ongoing harm is itself the basis of a continuing controversy between the parties. ${ }^{84}$ Requiring the plaintiff to supplement his proof would serve no purpose.

In several other substitution cases involving behavior similar to the conduct challenged in Spomer, mootness has not been found where the conduct was apparently based on an official and longstanding policy. Patterson $v$. McDougall, ${ }^{65}$ for example, involved a pro se complaint filed by inmates of a Georgia prison against the Director of the Georgia State Board of Corrections seeking to enjoin the continuation of an alleged tradition of brutal mistreatment, racial and religious discrimination and deprivation of various con-

3) The opinion does not clearly specify whether the succession occurred during the trial or in the period after the trial ended but before the decree issued. Id. at 871 .

- Id. at 870 . The dump had grown so large that affirmative corrective measures were necessary to prevent further damage to nearby properties.

"Id. at 871-72.

'2 E.g., Lucas v. Gardner, 453 F.2d 1255 (4th Cir. 1972); Alcoa Steamship Co. v. Perez, 424 F.2d 433 (1st Cir. 1970); Vermont v. Brinegar, 379 F. Supp. 606 (D. Vt. 1974); Adamian v. University of Nebraska, 359 F. Supp. 825 (D. Nev. 1973); City of New York v. Ruckelshaus, 358 F. Supp. 669 (D.D.C. 1973); Moore v. Knowles, 333 F. Supp. 53 (N.D. Tex. 1971), aff'd in part and vacated in part on other grounds, 482 F.2d 1069 (5th Cir. 1973); Spivac v. Gardner, 268 F. Supp. 366 (E.D.N.Y. 1966); Hudson v. Celebrezze, 220 F. Supp. 738 (E.D.N.C. 1963).

is A finding of mootness would not necessarily turn on whether the relief sought was mandatory rather than prohibitory since mandatory relief is often sought to assist enforcement of an essentially preventive decree.

"This conclusion assumes, of course, that the plaintiff's right to reparative relief survives the succession in office. Cf. Sarteschi v. Burlein, 508 F.2d 110 (3d Cir. 1975). Compare Moore v. Knowles, 333 F. Supp. 53 (N.D. Tex. 1971) (wrongful dismissal action not mooted by change-over in composition of defendant Board of Trustees), with Hirsh v. Green, $382 \mathrm{~F}$. Supp. 187 (D. Md. 1974), (wrongful dismissal action moot when defendant-officers at whose sufferance plaintiff served left office).

is 506 F.2d 1 (5th Cir. 1975). 
stitutional rights. After the district court had dismissed the complaint on technical grounds, the named defendant was succeeded; the court of appeals reviewed the merits of the dismissal in spite of the succession and found the dismissal improper. Although the successor had not moved to declare the case moot, the remand order nonetheless included an instruction to the district court to examine the mootness question raised by the succession. The court of appeals doubted, however, that the case was moot under Spomer because "[here] the wrongdoing is alleged to permeate many levels of prison personnel, and, if proved, would likely require relief to correct institutionalized abuses." 66 The challenged conduct was further described as "pervasive and long-continued." 67

Even though acts of racial discrimination were held to be "personal" in Spomer, Patterson appears to stand for the proposition that such presumptively personal misconduct will, for mootness purposes, be considered "official" if part of a pervasive tradition of such misconduct. ${ }^{68} \mathrm{~A}$ court could readily assume that such longstanding institutional practice is likely to be continued by the successor. If the successor desires to reverse the contested policy, it seems less burdensome to require him to disavow the policy rather than to subject the plaintiff to the possibility of further harm. If he does not, there is no reason to delay a decision on the merits. Numerous decisions predating Spomer appear to support this view ${ }^{69}$

Spomer also has not controlled in cases where the successor is called upon to perform an essentially ministerial act and thus is only a nominal defendant. Ford $v$. Hollowell, ${ }^{70}$ for example, was a proceeding against the Superintendent of the Mississippi State Penitentiary for a writ of habeas corpus. The petitioner claimed that his conviction was invalid because it had allegedly been based on an indictment of a grand jury from which blacks were systematically

506 F.2d at 6 n.5. In Spomer, the Court noted that the question of whether "effective relief would call for corrective behavior" by the successor was important in determining whether the controversy survived the succession.

67 Id. at 3.

${ }^{88}$ See text and note at note 40 supra.

or See, e.g., Barnett v. Rogers, 410 F.2d 995 (D.C. Cir. 1969); Lankford v. Gelston, 364 F.2d 197 (4th Cir. 1966); United States v. Logue, 344 F.2d 290 (5th Cir. 1965); United States v. Atkins, 323 F.2d 733 (5th Cir. 1963); United States v. Dothard, 373 F. Supp. 504 (M.D. Ala.), aff'd sub nom., NAACP v. Allen, 493 F.2d 614 (5th Cir. 1974); NAACP v. Allen, 340 F. Supp. 703 (M.D. Ala. 1972); Coleman v. Aycock, 304 F. Supp. 132 (N.D. Miss. 1969); Lee v. Board of Education, 267 F. Supp. 458 (M.D. Ala. 1967). See also Roberts v. Taylor, 390 F. Supp. 705 (D.R.I. 1975).

${ }^{70} 385$ F. Supp. 1392 (N.D. Miss. 1974). For a similar case, see Dyer v. Blair, 390 F. Supp. 1287 (N.D. Ill. 1974). 
excluded. Despite a succession in the office of Superintendent, the court reached the merits without discussing either Spomer in particular or mootness in general. But the court's silence may have an explanation. Since the successor never argued that the case was moot, dismissal for mootness would have been proper, under the suggested reading of Spomer, only if the court were certain that the succession had deprived it of jurisdiction. The court in Hollowell could not make such a finding; although the predecessor had not personally perpetrated the alleged wrongful behavior, the successor was the official capable of granting the desired relief. For the purposes of correcting the wrong, it did not matter whether the predecessor or the successor was the current office holder and therefore the nominal defendant. ${ }^{71}$

In a final category of cases, the courts have reached the merits after substitution without pausing to examine mootness despite the personal nature of the underlying behavior. These cases involve attempts to disturb the exercise of the defendant's prosecutorial discretion, an area of behavior that would, especially after Spomer, appear to be highly personal. Yet an action to enjoin the Attorney General and the U.S. Attorney for the District of Columbia to exercise their discretion to initiate prosecutions under the seldom enforced 1925 Federal Corrupt Practices Act was not found to have been mooted by succession in Nader $v$. Saxbe. ${ }^{72}$

It is peculiar that the court in Nader $v$. Saxbe did not trouble to distinguish its case from Spomer, the misconduct in both cases involving alleged improprieties in the exercise of prosecutorial discretion. There are logical grounds on which the cases might be dis-

"In a sense, a habeas corpus case is not a suit for injunctive relief in futuro but is an action to remedy the continuing injury of unconstitutional imprisonment; it should therefore be outside of Spomer on this ground as well. For examples of pre-Spomer cases against nominal defendants called upon to perform essentially ministerial tasks which were held not to have been mooted by succession, see Smith v. Cherry, 489 F.2d 1098 (7th Cir. 1973) (suit to void an election); Aikens v. Gomes, 367 F. Supp. 401 (D. Ariz. 1972); Sims v. Amos, 336 F. Supp. 924 (M.D. Ala. 1972) (reapportionment).

72 497 F.2d 676 (D.C. Cir. 1974). Similarly, an action to enjoin the Secretary of the Florida Department of Health and Rehabilitative Services from enforcing an allegedly unconstitutional state statute survived a substitution in Owens v. Roberts, 377 F. Supp. 45 (M.D. Fla. 1974). It is easier to understand why the Owens case was not mooted by the succession than it is in Saxbe. The underlying complaint in Saxbe was that the predecessors had abused their prosecutorial discretion; such abuse is not readily attributable to the successors. In Owens, on the other hand, the underlying complaint was that the statute being enforced was unconstitutional; the merits of this complaint were not at all dependent upon the identity of the nominal defendant.

For similar pre-Spomer cases, see, e.g., Vermont v. Brinegar, 379 F. Supp. 606 (D. Vt. 1974); Carlson v. Schlesinger, 364 F. Supp. 626 (D.D.C. 1973); City of New York v. Ruckelshaus, 358 F. Supp. 669 (D.D.C. 1973); Jenness v. Forbes, 351 F. Supp. 88 (D.R.I. 1972). 
tinguished, but the court chose not to mention them. For example, in Spomer the alleged misconduct was malicious and not alleged to be part of a long-standing tradition; it was relatively unlikely that it would be continued by the successor. In Saxbe, on the other hand, the alleged misconduct was traditional and pervasive; the court could have assumed that it would be likely to be repeated if the successor was unwilling to disavow it. In any event, cases such as Saxbe demonstrate the strong tendency of the lower courts to confine Spomer to its precise facts, by brute force if necessary. ${ }^{73}$

Other than in cases of continuing harm or where the officer is only a nominal defendant, the lower courts have not yet articulated clear standards for determining when Spomer will require a plaintiff seeking an injunction in futuro against a government officer in his official capacity to demonstrate that the action has not been mooted by a succession in office. The cases suggest, however, that the courts have implicitly been applying Spomer in one of two ways. First, the cases could be read only as establishing that in certain defined circumstances the plaintiff will not be burdened with establishing non-mootness. Other situations are presumably to be analyzed on a case-by-case basis. Such a reading, however, leaves certain questions unanswered: Does Spomer represent the exception, or is it the rule? How does a court determine whether to follow Spomer in any given case? If Spomer is applied, how does a court establish what the plaintiff must do in order to continue the case? It would thus seem necessary, in the absence of a principal rule, to decide the unsettled cases on the basis of a somewhat mysterious and ad hoc examination of the facts involved.

Second, it could be argued that the cases, when taken as a whole, establish a straightforward procedural rule: unless, as in Spomer, the court is so confident that the successor will not continue the predecessor's behavior-in other words, that the predecessor's behavior was "personal," however that term is defined-the court will proceed to the merits unless the successor affirmatively establishes the case is moot. Such a procedure would not unduly

73 The Saxbe and Owens courts might have been mindful that a broad reading of Spomer would reinvigorate Ex parte La Prade, 289 U.S. 444 (1933), a case which the Advisory Committee Notes expressly disapproved, see note 28 supra. In Ex parte La Prade the Supreme Court held that an action seeking to enjoin a state attorney general from enforcing an allegedly unconstitutional statute was mooted upon the incumbent's separation from office. The Court noted that the successor might not follow the predecessor's personal policy and might, in other words, refuse to enforce the law. See Allen v. Regents of the University System of Georgia, 304 U.S. 439 (1938). See also Two Guys from Harrison-Allentown, Inc. v. McGinley, 366 U.S. 582,588 (1961). 
conflict with rule 25(d)'s general principle of requiring the successor affirmatively to establish mootness. That policy would be sacrificed only in the rare cases where the court was certain that the successor was unlikely to continue the contested policies; in such cases the plaintiff would be unlikely to be prejudiced by the finding of mootness. In the great majority of cases, the successor would either assent to continuing the litigation or attempt to establish mootness. Although this rule would be defensible in light of the policies of amended rule $25(\mathrm{~d}),{ }^{74}$ the courts have not expressly purported to follow it.

\section{Related Doctrinal Principles}

Outside the context of a rule $25(\mathrm{~d})$ substitution, settled rules determine when a successor is bound by an injunction issued against his predecessor and when a defendant in an action for injunctive relief can moot the action by alleging that the challenged conduct will not be repeated. An examination of these rules and the policies that underlie them suggests the propriety of generally requiring a rule $25(d)$ successor to establish mootness if he wishes to avoid continuation of the litigation.

\section{A. The Obligation of Successors to Honor Injunctions Issued Against Their Predecessors}

At common law, an injunction was binding not only against its specific addressee, but also against privies of the addressee who had notice of the decree. ${ }^{76}$ The concept of privity has been used to define the class of persons who, although not parties to the proceeding in which the decree was issued, will be bound by the decree because their interests in the matter are closely related to those of the addressee. If only the addressee himself were bound, he could easily

\footnotetext{
"See text and notes at notes 27-33 supra.

is Such a rule would not, moreover, require the courts to undertake the unwieldy task of determining when behavior is likely to be continued by a successor. Since the presumption is that the behavior will be continued in all but the unusual cases, the successor will bear the burden of going forward to establish that the behavior will not be repeated. If the court is not certain that the behavior is unlikely to be repeated and the successor does not attempt to go forward, the litigation will not be interrupted by the substitution. To combat a successful demonstration, the plaintiff should be entitled to supplement his pleadings to show, for example, that the predecessor's policies were not original with him but were based on a longstanding official tradition.

" See Regal Knitwear Co. v. NLRB, 324 U.S. 9 (1945); United States v. Dean Rubber Mfg. Co., 71 F. Supp. 96, 98 (W.D. Mo. 1946). See generally 7 J. Moore, Federal Practice I 65.13 at 110 (2d ed. 1974).
} 
circumvent the injunction by having others act on his behalf. ${ }^{77}$ Thus, an agent of the addressee who knowingly transgresses the injunction ${ }^{78}$ or a non-agent who knowingly aids and abets a violation of the decree ${ }^{79}$ will be held to be in contempt of court.

The policy of ensuring the integrity of injunctive decrees does not necessarily require that successor officers be bound by their predecessor's injunctions. If the successor was not appointed in order to thwart the decree, it could be argued that he should not be held to be a privy ${ }^{80}$ Yet in two older cases, the Supreme Court held that successors were required to honor injunctions that had been issued against their predecessors, even though the successors had evidently been appointed in good faith. ${ }^{81}$ The Court reasoned that since the original relief ran against the office of the successor, the successor could not have independent justification for engaging in the proscribed behavior. ${ }^{82}$

This doctrine has persisted to the present; several recent federal cases have held that successors are bound by final injunctions addressed to their predecessors ${ }^{83}$ subject to the right to attempt to modify or dissolve the decree in equity. ${ }^{84}$ In Lucy $v$. Adams, ${ }^{85}$ for example, the successor of a Dean of Admissions at the University of Alabama sought construction of an injunction issued to his predecessor. The predecessor had been enjoined from pursuing an admissions policy based on racial discrimination. After commenting on the strong identity of interest between the predecessor and the successor, the court expressed fear that the original decree would be thwarted if the successor were not bound, even though it had not found that the successor had been appointed to circumvent the order ${ }^{86}$ The court held that the decree would bind the new Dean as

7 See, e.g., Crucia v. Behrman, 147 La. 137, 84 So. 523 (1920).

${ }^{78}$ Baltimore \& O.R.R. v. Chicago River \& Ind. R.R., 170 F.2d 654 (7th Cir. 1948); Helena Glendale Ferry Co. v. Walling, 132 F.2d 616 (8th Cir. 1942).

"Chase Nat'l Bank v. City of Norwalk, 291 U.S. 431 (1934); McGraw-Edison Co. v. Preformed Line Prods. Co., 362 F.2d 339 (9th Cir. 1966).

8s Cf. Note, Binding Non-parties to Injunction Decrees, 49 MinN. L. Rev. 719, 728 (1965).

81 Gunter v. Atlantic Coast Line, 200 U.S. 273 (1906); Prout v. Starr, 188 U.S. 537 (1903).

${ }^{82}$ See Note, supra note 80 , at 728 .

Lucy v. Adams, 224 F. Supp. 79 (N.D. Ala. 1963), aff'd sub nom., McCorvey v. Lucy, 328 F.2d 892 (5th Cir. 1964); Wright v. County School Board, 309 F. Supp. 671 (E.D. Va. 1970), rev'd sub nom., Wright v. Council of City of Emporia, 442 F.2d 570 (4th Cir. 1971), rev'd, 407 U.S. 451 (1972).

s Acheson v. Albert, 195 F.2d 573 (D.C. Cir. 1952); see note 87 infra. See also cases cited in note 83 supra; 6B J. Moore, supra note 76, I 60.26(4) (2d ed. 1974).

224 F. Supp. 79 (N.D. Ala. 1963).

${ }^{86}$ The court evidently concluded that Fed. R. Civ. P. 65(d) incorporates the common law rule concerning the obligation of successors to addressees of injunctions. Rule 65(d) states: 
well as all other university officials with knowledge of it. In essence, the entire Admissions Office was held to be bound by the original injunction.

The principle of the Lucy case serves to protect not only the plaintiff's established rights but also the court's resources. The plaintiff is not required to go through a potentially endless stream of litigation to prevent future office holders from engaging in behavior that he has once established to be wrongful. Similarly, the court is not required to hear essentially the same case over and over again, a redundancy that the principle of res judicata prevents in cases involving the same parties. The Lucy doctrine does not, moreover, operate to the undue prejudice of the successor since the injunction can be equitably dissolved upon a proper showing. ${ }^{87}$

Although the $L u c y$ doctrine is firmly rooted in the law, it is not directly controlling where the successor takes office before the injunctive decree is issued. Nevertheless, the policy underlying the doctrine suggests that it is proper in those cases to require the successor either to disavow the contested policy or defend its lawfulness. Just as the mere fact of succession is an insufficient reason for a court to emasculate an injunction issued against the predecessor officer in his official capacity, the substitution of a successor officer during such litigation should also be an insufficient reason in and of itself for the court to assume that the pending action has become moot if the plaintiff cannot demonstrate otherwise. In either case, the identity of the interests and the likelihood of continuity in policy call for analogous results: if the injunction has issued, the successor

Every order granting an injunction and every restraining order . . . is binding only upon the parties to the action, their officers, agents, servants, employees, and attorneys, and upon those persons in active concert or participation with them who receive actual notice of the order by personal service or otherwise.

See cases cited in note 76 supra.

"It is interesting that in Spomer the successor was not required to defend the legality of the predecessor's racial discrimination whereas in Lucy the successor was held to be bound by a decree prohibiting the predecessor from continuing his discrimination.

It is well settled that an injunction governing a continuous course of conduct may be modified or dissolved in equity if circumstances unforeseen when the decree issued make application of the injunction to the unforeseen circumstances a hardship. FED. R. CIv. P. 60(b); United States v. Swift \& Co., 286 U.S. 106 (1932); Western Union Tel. Co. v. International Bhd. of Elec. Workers, 133 F.2d 955 (7th Cir. 1943); see Developments in the LawInjunctions, 78 Harv. L. Rev. 994 (1965); Note, The Power of a Court to Modify a Final Permanent Injunction, $46 \mathrm{MICH}$. L. REv. 241 (1947).

A credible change in the attitude of the addressee may also justify modification or dissolution of the decree. Tobin v. Little Rock Packing Co., 202 F.2d 234 (8th Cir. 1953); Tobin v. Alma Mills, 192 F.2d 133 (4th Cir. 1951); Comment, Dissolution and Modification of Federal Decrees on Grounds of Change of Attitude, 25 U. CHI. L. REv. 659 (1958); 11 C. Wright \& A. Miller, Federal Practice and Procedure § 2961, at 606-07. 
should be bound; if the injunction has only been sought, the successor should defend.

\section{B. Voluntary Cessation and the Discontinuance Doctrine}

One of the issues addressed by the Supreme Court in United States $v$. W.T. Grant Co. ${ }^{88}$ was whether the defendant's voluntary cessation of the behavior challenged in a case for injunctive relief would constitute a sufficient reason to find the case moot. The Government had sought to enjoin an individual under the Clayton Act from serving as a director of the boards of certain competing corporations. In an attempt to moot the action, the individual defendant resigned a sufficient number of his memberships to eradicate the conflict and promised never to resume those memberships. The Court refused to view the case as moot, remarking that the defendant had not met the "heavy" 89 burden of demonstrating that "there is no reasonable expectation that the wrong will be repeated." Since W.T. Grant, it has become well established that, in the absence of external factors that make repetition of the challenged conduct unlikely, ${ }^{91}$ voluntary cessation will moot an action only if the defendant admits the illegality of his conduct in addition to his promise not to repeat it. ${ }^{92}$

83345 U.S. 629 (1953). See also United States v. Oregon State Medical Soc'y, 343 U.S. 326 (1952); Atlantic Richfield Co. v. Oil, Chemical \& Atomic Workers, 447 F.2d 945 (7th Cir. 1971).

345 U.S. at 633. See also Walling v. Mutual Wholesale Food \& Supply Co., 141 F.2d 331, 334 (8th Cir. 1944).

so The Court refused to grant the injunction, however. It stated that injunctive relief required "some cognizable danger" of repetition-"something more than the mere possibility which serves to keep the case alive." 345 U.S. at 633 (emphasis supplied).

" Compare SEC v. Medical Comm. on Human Rights, 404 U.S. 403 (1972), with United States v. Concentrated Phosphate Export Ass'n, 393 U.S. 199 (1968). See also text and note at note 94 infra.

${ }_{22}$ See, e.g., United States v. Trans-Missouri Freight Co., 166 U.S. 290, 308 (1897); Walling v. Helmerick \& Payne, 323 U.S. 37, 43 (1944); United States v. Aluminum Co. of America, 148 F.2d 416, 448 (2d Cir. 1946); Consumers Union of the United States, Inc. v. Veterans Administration, 436 F.2d 1363 (2d Cir. 1971); Cherry v. Postmaster General, 332 F. Supp. 785 (S.D.N.Y. 1971), aff'd, 460 F.2d 1063 (2d Cir. 1972).

Although it has been suggested that an admission of illegality might be insufficient to moot the action, Note, The Mootness Doctrine in the Supreme Court, 88 HARv. L. REv. 373, 384 (1974), the weight to be accorded an admission is likely to depend on such factors as the character of the past misconduct, and the ability of the defendant to control repetition of the behavior, particularly where government officers are defendants. Compare Lankford v. Gelston, 364 F.2d 197 (4th Cir. 1966), and United States v. Atkins, 323 F.2d 733 (5th Cir. 1963), with Cherry v. Postmaster General, 332 F. Supp. 785 (S.D.N.Y. 1971), aff'd, 460 F.2d 1063 (2d Cir. 1972), and United States ex rel. Wakeley v. Pennsylvania, 247 F. Supp. 7 (E.D. Pa. 1965). 
Two closely related policies underlie the so-called discontinuance doctrine: preservation of judicial resources and protection of the plaintiff's interests..$^{93}$ If the litigation has approached completion before the defendant's recantation, a finding of mootness would possibly compel an unnecessary expenditure of judicial resources in the future to retry the issue. A person who is unwilling to defend the legality of his contested behavior or admit its illegality can logically be presumed likely to repeat it. On the other hand, a court would have less reason to fear that its resources would be wasted if the recantation were coupled with an admission of illegality; a person would be unlikely, and probably foolish, to resume conduct that he has freely admitted to be illegal. Without tangible assurance that repetition is unlikely, ${ }^{94}$ judicial economy is best served by early litigation, regardless of its eventual outcome.

The discontinuance doctrine also protects the interests of the plaintiff. If voluntary cessation were to moot these cases, the plaintiff would be forced to endure more harm or the threat of more harm before being entitled to attempt to demonstrate that he is entitled to injunctive protection..$^{95}$ A plaintiff who has alleged to have already suffered legal prejudice should be able to have his claim adju-

's See Kates \& Barker, Mootness in Judicial Proceedings, 62 CaLIF. L. REv. 1385, 1413 (1974):

If the dispute is sufficiently likely to recur . . . judicial economy will be served by a decision that will forestall future litigation. Moreover decision of a case which is likely to recur better protects the rights of victims than a decision delayed until harm has again recurred.

See also Note, The Mootness Doctrine in the Supreme Court, 88 HaRv. L. REv. 373, 388 (1974); Note, Mootness on Appeal in the Supreme Court, 83 HaRv. L. REv. 1672, 1675 (1970).

" A defendant may also establish mootness by persuading the court that changed circumstances make repetition of the challenged conduct exceedingly unlikely. In United States v. Concentrated Phosphate Export Ass'n, 393 U.S. 199 (1968), the Court rejected such a claim and remanded the case for a determination of whether the injunction should issue. The defendant association argued that a change in the regulations of the Agency for International Development made the continued existence of the association uneconomical, but the Court held that the "stringent standard" for establishing mootness had not been met because there was a "reasonable possibility" that the member companies would re-organize in another form. Id. at 203. See also Barnett v. Rogers, 410 F.2d 995 (D.C. Cir. 1969); Jackson v. Bishop, 404 F.2d 571 (8th Cir. 1968); Anderson v. City of Albany, 321 F.2d 649 (5th Cir. 1963); City of Montgomery v. Gilmore, 277 F.2d 364 (5th Cir. 1960); United States v. Aluminum Co. of America, 148 F.2d 416 (2d Cir. 1945). The stringent standard for establishing mootness in these cases is entirely appropriate: neither the plaintiff nor the judicial system should be exposed to the possibility of a renewal of the alleged misconduct if the defendant is not willing to admit the illegality of his actions and cannot persuasively demonstrate that external forces would prevent him from repeating the conduct even if he tried.

is See text and note at note 87 supra. The plaintiff's interests may be best served by immediate litigation even if he is unable to prevail eventually on the merits; in that case the plaintiff may be better off if he is forced to adjust to the reality of the legality of the defendant's behavior immediately rather than later. 
dicated without unnecessary delay. Moreover, it is difficult to conclude that the discontinuance doctrine prejudices the defendant even if he were to be enjoined from engaging in behavior he sincerely intended to abandon. ${ }^{96}$ Although the defendant would have to $a b-$ sorb litigation expenses to defend such a suit, such prejudice seems insignificant when it is recalled that it was his alleged misconduct that generated the lawsuit in the first place; the legal system generally requires an individual to defend his actions at his own expense.

However, because the voluntary cessation cases resolve the mootness issue on the basis of the likelihood of repetition of the challenged behavior by the one originally engaged in it, the doctrine could be viewed as having only limited applicability in succession cases where the successor has an unblemished record. But here again, the policy underlying the doctrine-that a case should not be found moot when there is a reasonable likelihood of recurrence of the challenged behavior-can be applied in full force. The fact the the successor has an as yet unblemished record does not alter the relevant inquiry-whether the behavior is likely to be repeated-although it should enable the successor to moot the case through voluntary cessation with greater ease. ${ }^{97} \mathrm{~A}$ finding of mootness is not warranted if there is a reasonable likelihood that the challenged conduct will be repeated. In Spomer the Court could reasonably conclude that the successor was not apt to continue the predecessor's personal policy of racial malice; a finding of mootness was therefore reasonable. In most of the lower court cases, however, such a finding could not be made and the courts quite properly reached the merits after noting the substitution.

\section{ConcLusion}

Since a moot case is not a "case or controversy" within the meaning of article III, section 2 of the Constitution, a federal court has no jurisdiction to decide it. It is not always readily apparent, however, whether a case is moot or not. In particular, it is exceptionally difficult to ascertain whether a case in which in futuro injunc-

${ }^{96}$ This argument was made in NLRB v. General Motors Corp., 179 F.2d 221, 222 (2d Cir. 1950), cited with approval in United States v. W.T. Grant Co., 345 U.S. 629, 632 (1953); see Kates \& Barker, supra note 93, at 1414-15. At 1415 n.167 the authors quote from Vaughan v. John C. Winston Co., 83 F.2d 370, 374 (10th Cir. 1936):

If, except for the injunction, Vaughan would have continued to send out the defamatory circulars then the order concededly was proper; if he did not so intend, then he is not hurt by the order. His appeal from that part of the order indicates that it hurts; but it can only hurt if he desires to resume his unlawful acts.

"See text and notes at notes 99-100 infra. 
tive relief is sought against a government officer in his official capacity is mooted when his successor is substituted under the automatic procedure of rule 25(d) of the Federal Rules of Civil Procedure. Given the difficulty of accurately predicting the successor's future actions, the choice of presumption in this situation-mootness or non-mootness-and the corresponding allocation of the burden of overcoming the presumption may often be dispositive.

Several practical factors suggest that the burden of demonstrating mootness should generally be on the successor. First, in acceding to the predecessor's office, the successor inherits the predecessor's duties, powers, objectives, and, quite possibly, priorities as well. This strong identity of interests will often generate a consistency in official behavior and attitude that overlaps separate tenures. Moreover, if, in light of this strong identity, the successor does not argue that the contested conduct was personal to the predecessor and thus that the case has become moot, it seems reasonable to assume that he will continue the behavior. Second, a finding of mootness will give the successor a grace period in which he can continue his predecessor's challenged policies without fear of sanction; this grace period exposes the plaintiff to further harm of the nature he has already attempted to challenge. Third, as a matter of practicality it will be much easier for the successor to establish mootness by disavowing the contested policy than it will be for the plaintiff to establish non-mootness by demonstrating a continuation or threat of continuation of the challenged conduct. A successor may be able to avoid judicial review of the contested policies for quite some time while permitting the cloud of possible resumption to hang over the plaintiff's head. Finally, judicial economy is not well served by dismissing litigation that is in progress when there is a likelihood that the proceedings will eventually have to be repeated.

The relevant legal factors also suggest the propriety of presuming that an action has not been mooted by substitution. Rule 25(d), when viewed in light of the Advisory Committee's notes, seems intended to burden the successor with establishing mootness after substitution. Furthermore, the policies of the Lucy doctrine and the discontinuance doctrine-preservation of the plaintiff's interests in achieving a binding resolution on the merits and efficient use of judicial resources-also call for burdening the successor.

In Spomer and a handful of cases decided directly under it, the courts have departed, however, from the principle of requiring the defendant to establish non-mootness. Since the Spomer Court in all probability did not intend to re-establish the practice of requiring plaintiffs to establish non-mootness, it is important to determine 
when Spomer shifts the burden to the plaintiff. If Spomer is to remain the exception instead of becoming the rule, a court should shift the burden to the plaintiff only when convinced that the predecessor's policy was so personal that the successor would be unlikely to repeat the wrongful actions. The successor should bear the burden of establishing mootness in all but the rare cases where the court is confident that the substitution has certainly mooted the action. This rule would not seriously conflict with the policies of amended rule $25(\mathrm{~d})$-the burden would be on the successor in most cases-and would comport with the policies of the Lucy and discontinuance doctrines; the plaintiff would be required to establish non-mootness only where it seemed certain that neither the legal system nor the plaintiff would suffer as a result.

Finally, if the successor will typically bear the burden of establishing mootness, it is important to determine what he must do to perform that task. In the voluntary cessation cases, the courts have tended to require more than a statement of intent not to continue the challenged behavior, and have at times sought a confession of illegality or a demonstration of compelling external circumstances as additional requirements. ${ }^{98}$ Yet in cases where a government official offers to discontinue his challenged behavior, the courts appear to be satisfied with an apparently good faith disavowal..$^{99}$ Importing this lesser standard of proof seems entirely appropriate where the successor offers to discontinue his predecessor's behavior. Since the identity of interest between the successor and the predecessor is not absolute and the successor has as yet done no wrong, the court should have little reason to fear that the disavowal is a sham. ${ }^{100}$

Arthur F. Sampson III

${ }^{93}$ E.g., United States v. W.T. Grant Co., 345 U.S. 629 (1953); see text and notes at notes 88-97 supra; cf. United States v. Concentrated Phosphate Export Ass'n, 393 U.S. 199 (1968); Note, The Mootness Doctrine in the Supreme Court, 88 HARv. L. REv. 373, 384 (1974).

" Consumers Union of the United States, Inc. v. Veterans Administration, 436 F.2d 1363 (2d Cir. 1971); Belknap v. Leary, 427 F.2d 496 (2d Cir. 1970); Cherry v. Postmaster General, 332 F. Supp. 785 (S.D.N.Y. 1971), aff'd, 460 F.2d 1063 (2d Cir. 1972); United States ex rel. Wakeley v. Pennsylvania, 247 F. Supp. 7 (E.D. Pa. 1965).

${ }^{100}$ See, e.g., Four Star Publications, Inc. v. Erbe, 304 F.2d 872 (8th Cir. 1962).

The court may wish to vary the burden in accordance with the circumstances. Where the challenged policy is government-wide and has persisted through several successions, a good faith disavowal may be insufficient. See, e.g., United States v. Atkins, 323 F.2d 733 (5th Cir. 1963). The successor should not be able to shift the burden to the plaintiff by merely alleging his belief that the predecessor's alleged misconduct was personal under Spomer and therefore not attributable to him but otherwise refusing to disavow the policy. If the court would not have been willing to conclude on its own motion that the challenged conduct was so personal as to moot the case, then the successor should be required either to disavow or defend. The successor's statement of belief should not by itself be sufficient to persuade a court that the challenged conduct was not likely to.be repeated. 